\title{
HUBUNGAN TINDAKAN KERJA DAN KONDISI KERJA DENGAN KECELAKAAN KERJA PADA PEKERJA BAGIAN TIANG BESI DI PT. X KOTA PADANG TAHUN 2017
}

\author{
Fadillah Ulva $^{1}$, Ledia Restipa ${ }^{2}$ \\ 1. STIKes Alifah Padang, Sumatera Barat \\ Email: dilla_ulva@yahoo.com \\ 2. STIKes Alifah Padang, Sumatera Barat \\ Email : ledia_restipa@yahoo.com
}

\begin{abstract}
ABSTRAK
Tenaga kerja di PT. X pernah mengalami kecelakaan kerja pada tahun 2016 sebanyak 10 orang sewaktu bekerja. Ini dikarenakan kondisi ruang kerja yang tidak aman seperti kabel las yang terbuka, peralatan kerja yang berserakan dan tindakan masih ada pekerja yang tidak menggunakan alat pelindung diri seperti kaca mata las dan sepatu. Tujuan penelitian ini adalah untuk mengetahui hubungan tindakan dan kondisi kerja dengan kecelakaan kerja pada Pekerja Bagian Tiang Besi di PT. X Kota Padang tahun 2017.Jenis penelitian analitik dengan desain cross sectional. Populasi pada penelitian ini yaitu seluruh pekerja dibagian tiang besi PT. X berjumlah 37 orang. Teknik pengambilan sampel menggunakan total sampling. Penelitian dilakukan bulan Januari - Agustus 2017. Data dianalisis secara univariat dan bivariat dengan tingkat kemaknaan 95\% $\quad \alpha=0,05$. Hasil penelitian menunjukkan $35,1 \%$ responden pernah mengalami kecelakaan kerja. 43,2\% responden memiliki tindakan tidak aman. Sebanyak 37,8\% responden memiliki kondisi tidak aman. Ada hubungan tindakan kerja dengan kecelakaan kerja. Ada hubungan kondisi kerja dengan kecelakaan kerja di PT. X Kota Padang tahun 2017. Faktor tindakan dan kondisi kerja mempengaruhi terjadinya kecelakaan kerja. Diharapkan pimpinan perusahaan dapat mengevaluasi penerapan K3 dengan melakukan safety briefing pada pekerja yang dapat meninjau kembali keadaan kerja pada bagian tiang besi dan menyarankan pada pekerja untuk merapikan alat dan bahan serta perusahaan dapat menyediakan tempat pembuangan sampah bekas kerja.
\end{abstract}

Kata Kunci : Keselamatan dan Kesehatan Kerja, Kecelakaan kerja, tindakan kerja,

\section{ABSTRACT}

Workers at PT. X had 10 work accident in 2016. This is due to unsafe workspace conditions such as open welding cables, scattered work equipment and worker action that does not use personal protective equipment such as welded glasses and shoes. The purpose of this study is to determine the relationship of action and working conditions with work accidents on the Worker Pill Iron at PT. X Padang in 2017.This in an analytic research with cross sectional design. Population of this study was all workers at iron pole section of PT. X which amounted 37 people. This study used total population. The study was conducted from January to August 2017. Data were collected on 06 - 17 June 2017. Data were analyzed computerized with univariate and bivariate. 
The results showed that $35.1 \%$ of respondents had experienced work accident. $43.2 \%$ of respondents had unsafe measures. 37.8\% of respondents have unsafe conditions. There is a relationship of unsafe actions and unsafe conditions with accidents at PT. X Padang.Factors of action and conditions affect the occurrence of work accidents. It is expected that company leaders can evaluate the implementation of health and safety by conducting safety briefing on workers who can review the working conditions on the iron pole and advise the workers to tidy up the tools and materials. And also, the company can provide used dump garbage.

Keywords: Safety and Health Occupational, work accidents, unsafe actions, unsafe conditions

\section{PENDAHULUAN}

Keselamatan dan kesehatan kerja merupakan salah satu aspek perlindungan tenaga kerja yang diatur dalam Undang-Undang Nomor 13 tahun 2003. Meskipun dalam ketentuan mengenai kesehatan dan keselamatan kerja telah diatur sedemikian rupa, tetapi dalam praktiknya tidak seperti yang diharapkan. Faktor yang terjadi dilapangan yang mempengaruhi kesehatan dan keselamatan kerja seperti faktor manusia, lingkungan dan psikologis. Masih banyak perusahaan yang tidak memenuhi standar keselamatan dan kesehatan kerja. Begitu banyak kecelakaan kerja yang dapat kita saksikan (Sucipto, 2014).

Pada saat ini penerapan standar keselamatan dan kesehatan kerja dalam setiap pekerjaan kontruksi merupakan keharusan bagi perusahaan jika ingin tetap bersaing. Hal ini menjadi sangat penting mengingat bahwa nyawa manusia merupakan suatu hal yang sangat berharga. Tetapi pada kenyataannya masih banyak dijumpai perusahaan atau pabrik yang kurang memperhatikan keselamatan kerja karyawan maupun pekerjanya (Aditama, 2012).

Data dari International Labour Organization (ILO) mencatat setiap hari terjadi sekitar 6000 kecelakaan kerja fatal di dunia. Di Indonesia sendiri, terdapat kasus kecelakaan yang setiap harinya dialami para buruh dari setiap 100 ribu tenaga kerja. Angka kecelakaan kerja secara nasional mencapai 8.900 kasus dari Januari hingga April 2014 dan 2500 kasus (BPJS Ketenagakerjaan, 2014).

Badan Penyelenggara Jaminan Sosial ketenagakerjaan mencatat kasus kecelakaan kerja mencapai 1.535 di Padang tahun 2016. Badan Penyelenggara Jaminan Sosial ketenagakerjaan mencatat kasus kecelakaan kerja mencapai 3.576 di Riau dan Sumatera Barat pada kuartal I tahun 2016 (BPJS Ketenagakerjaan, 2014).

Kecelakaan industri secara umum disebabkan oleh 2 hal pokok yaitu perilaku kerja yang tidak aman (unsafe actions) dan kondisi yang tidak aman (unsafe conditions). Penyebab kecelakaan kerja secara umum adalah karena adanya kondisi tidak aman dan tindakan tidak aman dari pekerja. Khusus mengenai unsafe action (tindakan tidak aman) ini sangat erat kaitannya dengan faktor manusia atau terjadi karena kesalahan manusia. Pekerja cenderung untuk berprilaku dengan mengabaikan keselamatan walaupun itu sangat berguna untuk kepentingannya sendiri, misalnya dalam melaksanakan tugas, pekerja sering kali tidak mengikuti langkah langkah yang sudah ditetapkan dalam Standard Operating Prosedure (SOP) (Silaban, 2014).

PT. X adalah perusahaan yang fokus dalam penyediaan, pemprosesan dan distribusi material baja dan beton siap pakai untuk industri konsruksi, kelistrikan, pertambangan, telekomunikasi dan perhubungan. Perusahaan ini berdiri pada tahun 2008 dengan menyediakan produk yang bermutu dan dapat diterima di pasar nasional maupun internasional. Perusahaan 
ini memiliki 3 bagian yaitu bagian pipa, tiang besi dan beton dengan jumlah karyawan sebanyak 325 orang, dimana pada bagian tiang besi berjumlah 37 orang.

Survey awal peneliti dilakukan pada tanggal 17 - 23 Januari 2017 dengan melakukan wawancara terhadap pimpinan PT. X mengatakan pernah terjadi kecelakaan pada tahun 2016 dari bulan Januari - Juni sebanyak 10 orang sewaktu bekerja. Ditemukan 6 orang mengalami luka pada mata, 2 orang luka pada kaki, luka pada jari tangan dan 2 orang luka pada kepala. Selain itu peneliti melakukan wawancara terhadap 10 pekerja, 3 orang lagi bekerja lebih dari 6 tahun. Dari 10 orang tersebut 6 orang mengatakan pekerjaan pada bagian tiang besi memiliki resiko kecelakaan kerja dengan kondisi dimana adanya kabel las yang terbuka dan 4 orang mengatakan tindakan masih ada pekerja yang tidak menggunakan alat pelindung diri seperti kaca mata las dan sepatu.

Adanya beberapa faktor yang dapat memicu terjadinya kecelakaan kerja tersebut, maka peneliti melakukan penelitian mengenai hubungan tindakan dan kondisi kerja dengan kecelakaan kerja pada pekerja di PT. X Kota Padangtahun 2017.

\section{METODE PENELITIAN}

Jenis penelitian yang digunakan adalah analitik dengan pendekatan cross sectional study, dimana pengumpulan data baik untuk variabel sebab (variabel independen) maupun variabel akibat (variabel dependen) dilakukan secara bersama-sama dalam waktu bersamaan. Penelitian ini dilakukan di PT. X Kota Padang. Waktu penelitian pada bulan Januari - Agustus 2017. Pengumpulan data di lakukan tanggal 06 - 17 Juni 2017. Populasi dalam penelitian ini adalah seluruh pekerja dibagian tiang besi PT. X yang berjumlah 37 orang. Seluruh populasi dijadikan sampel (total populasi). Teknik pengumpulan data yang dipergunakan dalam penelitian ini yaitu pengumpulan data primer dengan melakukan lembar observasi keterampilan motorik halus sebelum dan sesudah dilakukan terapi bermain. Penelitian ini menggunakan analisis Univariat dengan distribusi rerata motorik halus sebelum dan sesudah dilakukan terapi bemain dan analisis Bivariat

\section{HASIL DAN PEMBAHASAN}

A. Analisis Univariat

1. Kecelakaan Kerja

Tabel 1

Distribusi Frekuensi Responden Berdasarkan Kecelakaan Kerja di PT. X Kota Padang Tahun 2017

\begin{tabular}{llcc}
\hline No & Kecelakaan Kerja & $f$ & $\%$ \\
\hline 1. & Pernah & 13 & 35,1 \\
\hline 2. & Tidak Pernah & 24 & 64,9 \\
\hline & Jumlah & 37 & 100 \\
\hline
\end{tabular}

Berdasarkan tabel 1 dapat dilihat bahwa dari 37 responden, 35,1\% responden pernah mengalami kecelakaan kerja. Berdasarkan hasil penelitian diketahui sebanyak 18,2\% pernah terjepit oleh benda dan $21,6 \%$ pernah mengalami luka karena potongan besi. Hasil penelitian ini hampir sama dengan penelitian yang dilakukan oleh Ferdian (2016) tentang hubungan tindakan faktor-faktor yang berhubungan tidak aman (unsafe action) dan kondisi tidak aman (unsafe condition) dengan terjadinya kecelakaan kerja pada pekerja di Area Proyek Pembangunan Pabrik Indarung VI tahun 2016 ditemukan hasil kecelakaan kerja $(41,9 \%)$.

Kecelakaan kerja adalah kejadian yang tak terduga dan tidak diharapkan. Tak terduga, oleh karena dibelakang peristiwa itu tidak terdapat unsur kesengajaan, lebih-lebih dalam bentuk perencanaan. Maka dari itu peristiwa sabotase atau tindakan kriminal di luar ruang lingkup kecelakaan yang sebenarnya (Sucipto, 2014).

Analisis peneliti terjadinya kecelakaan kerja pada penelitian ini dapat disebabkan oleh 
karena pekerja ada yang tidak menggunakan alat pelindung diri hal ini dapat berakibat terkena benda-benda keras, debu, percikan api las dan terjepit. Hal ini dapat dilihat dari hasil observasi sebanyak $24,3 \%$ tidak menggunakan sarung tangan saat bekerja, $29,7 \%$ tidak menggunakan kaca mata saat bekerja, 24,3\% tidak menggunakan baju kerja saat bekerja.

\section{Tindakan}

\section{Tabel 2}

Distribusi Frekuensi Responden Berdasarkan Tindakan di PT. X Kota Padang Tahun 2017

\begin{tabular}{llcc}
\hline No & Tindakan & $f$ & $\%$ \\
\hline 1. & Tidak Aman & 16 & 43,2 \\
\hline 2. & Aman & 21 & 56,8 \\
\hline & Jumlah & 37 & 100 \\
\hline
\end{tabular}

Berdasarkan tabel 2 dapat dilihat bahwa dari 37 responden, 43,2\% responden memiliki tindakan tidak aman. Tindakan berbahaya (unsafe act/human error/tindakan-tindakan yang tidak standar) adalah tingkah laku, tindak-tanduk atau perbuatan yang akan menyebabkan kecelakaan, misalnya : Mengerjakan pekerjaan yang bukan tugasnya/tanpa perintah, membuat alat pengaman yang bukan tugasnya, menjalankan mesin dengan kecepatan yang membahayakan, murang pengetahuan dan keterampilan, tidak memakai atau salah memakai alat pelindung diri, kesalahan atau kegagalan memberikan peringatan atau keamanan (Silaban, 2014).

Selain itu mengabaikan tanda bahaya atau peringatan, memakai peralatan yang rusak, menggunakan peralatan tidak memadai atau sesuai, pembebanan atau penempatan yang salah, mengangkat dengan cara yang salah, penempatan sesuatu yang tidak memadai, posisi kerja yang tidak sesuai atau tidak aman, memperbaiku peralatan yang sedang bergerak, bekerja sambil bercanda, bekerja tidak konsentrasi, bekerja sambil merokok atau makan, meminum minuman keras (beralkohol) dan menggunakan obat-obatan terlarang, cacat tubuh yang tidak kentara, kelelahan dan kelesuan dan kondisi badan kurang sehat (Silaban, 2014).

\section{Kondisi Kerja}

Tabel 3

Distribusi Frekuensi Responden Berdasarkan Kondisi Kerja di PT. X Kota Padang Tahun 2017

\begin{tabular}{llcc}
\hline No. & Kondisi Kerja & $f$ & $\%$ \\
\hline 1. & Tidak Aman & 14 & 37,8 \\
\hline 2. & Aman & 23 & 62,2 \\
\hline & & 37 & 100 \\
& Jumlah & & \\
\hline
\end{tabular}

Berdasarkan tabel 3 dapat dilihat bahwa dari 37 responden, $37,8 \%$ responden memiliki kondisi kerja tidak aman. Kondisi berbahaya (unsafe conditions/kondisi-kondisi yang tidak standar) yaitu tindakan yang akan menyebabkan kecelakaan, misalnya (Silaban, 2014) Peralatan pengaman, pelindung, rintangan yang tidak memadai atau tidak memenuhi syarat; bahan, alat-alat atau peralatan rusak; terlalu sesak atau sempit; sistem-sistem tanda peringatan yang kurang mamadai; bahaya-bahaya kebakaran dan ledakan; kerapihan, tata-letak (housekeeping) yang buruk; lingkungan berbahaya, beracun (gas, debu, asap, uap); bising; paparan radiasi; serta ventilasi dan penerangan yang kurang.

Asumsi peneliti seorang pekerja dengan pekerjaan dan lingkungannya yang memberikan efek negatif atau tidak aman. Kondisi perusahaan yang didapatkan dari hasil penelitian masih ada kabel las yang terkelupas yang peralatan listrik dalam kondisi berserakan dan peralatan kerja tidak tersusun rapi. Hal ini menjadi salah satu penyebab timbulnya kecelakaan kerja. 
B. Analisis Bivariat

1. Hubungan Tindakan dengan Kecelakaan Kerja

Tabel 4

Hubungan Tindakan dengan Kecelakaan

Kerja di PT. X Kota PadangTahun 2017

\begin{tabular}{|c|c|c|c|c|c|c|c|}
\hline \multirow{3}{*}{ Tindakan } & \multicolumn{4}{|c|}{ Kecelakaan Kerja } & \multirow{2}{*}{\multicolumn{2}{|c|}{ Jumlah }} & \multirow{2}{*}{$\begin{array}{c}p \\
\text { value }\end{array}$} \\
\hline & \multicolumn{2}{|c|}{ Pernah } & \multicolumn{2}{|c|}{$\begin{array}{l}\text { Tidak } \\
\text { Pernah }\end{array}$} & & & \\
\hline & $f$ & $\%$ & $f$ & $\%$ & $n$ & $\%$ & \\
\hline $\begin{array}{l}\text { Tidak } \\
\text { Aman }\end{array}$ & 10 & 62,5 & 6 & 37,5 & 16 & 100 & 0,007 \\
\hline Aman & 3 & 14,3 & 18 & 85,7 & 21 & 100 & \\
\hline Jumlah & 13 & 35,1 & 24 & 64,9 & 37 & 100 & \\
\hline
\end{tabular}

Berdasarkan tabel 4 dapat dilihat bahwa proporsi responden yang pernah mengalami kecelakaan kerja lebih banyak pada tindakan tidak aman $(62,5 \%)$ dibandingkan dengan tindakan aman $(14,3 \%)$. Berdasarkan hasil uji statitik diperoleh $\mathrm{p}=0,007$, artinya terdapat hubungan yang bermakna tindakan tidak aman dengan kecelakaan kerja di PT. $\mathrm{X}$ Kota Padang

Peralatan pengaman/pelindung/rintangan yang tidak memadai atau tidak memenuhi syarat, bahan, alat-alat/peralatan rusak, terlalu sesak/sempit, sistem-sistem tanda peringatan yang kurang mamadai, bahayabahaya kebakaran dan ledakan. kerapihan/tata-letak (housekeeping) I buruk, lingkungan berbahaya atau ber' Kondisi (gas, debu, asap dan uap), bising, pap Kerja radiasi, serta ventilasi dan penerangan J kurang (Silaban, 2014).

Asumsi peneliti ditemukannya hubungahidak tindakan dengan kecelakaan kerja îmman dimana tindakan tidak aman lebih banyAman pernah mengalami kecelakaan kethymlah $(62,5 \%)$. Hal ini dapat dikarenakan masih ada pekerja yang memiliki pendidikan rendah (SD dan SMP) sebanyak 6 orang (16\%), pendidikan yang rendah ini membuat pekerja kurang informasi, salah paham, tidak yakin dengan alat yang digunakan, tidak dapat memutuskan suatu masalah dan tidak berpengalaman kerja, sehingga dapat memberi peluang untuk terjadinya kecelakaan kerja. Diharapkan pekerja mentaati prosedur kerja yang ada di bagian tiang besi dan selalu menggunakan alat pelindung diri dalam bekerja.

Selain itu ditemukan juga tindakan yang dilakukan oleh responden sudah masuk kategori aman, akan tetapi masih sering terjadi kecelakaan kerja (14,3\%). Hal ini berkemungkinan disebabkan oleh sebagian usia pekerja sudah tua. Pada usia yang sudah tua dengan kondisi fisik mulai berkurang akan berakibat pada kecelakaan kerja. Kemampuan organ akan menurun, menyebabkan tenaga kerja akan semakin mudah mengalami kelelahan yang berujung pada kecelakaan kerja contohnya penglihatan mata sudah mulai berkurang, daya pendengaran sudah mulai berkurang dan daya ketahanan tubuh sudah mulai menurun.

2. Hubungan Kondisi Tidak Aman dengan Kecelakaan Kerja

Tabel 5

Hubungan Kondisi Kerja dengan

Kecelakaan Kerja Tenaga Kerja di PT. X Kota PadangTahun 2017 
tidak aman (64,3\%) dibandingkan dengan kondisi aman $(17,4 \%)$. Berdasarkan hasil uji statistik diperoleh $\mathrm{p}=0,006$, artinya terdapat hubungan yang bermakna kondisi tidak aman dengan kecelakaan kerja di PT. X Kota Padang

Heinrich menekankan bahwa kecelakaan lebih banyak disebabkan oleh manusia. Menurutnya, tindakan dan kondisi yang tidak aman akan terjadi bila manusia berbuat suatu kekeliruan serta faktor karakteristik yang dipengaruhi keturunan dan lingkungan manusia itu sendiri. Kondisi berbahaya (unsafe conditions/kondisi-kondisi yang tidak standar) yaitu tindakan yang akan menyebabkan kecelakaan, misalnya Peralatan pengaman, pelindung, rintangan yang tidak memadai atau tidak memenuhi syarat; bahan, alat-alat atau peralatan rusak; terlalu sesak atau sempit; sistem-sistem tanda peringatan yang kurang mamadai; bahaya-bahaya kebakaran dan ledakan; kerapihan, tata-letak (housekeeping) yang buruk; lingkungan berbahaya, beracun (gas, debu, asap, uap); bising; paparan radiasi; serta ventilasi dan penerangan yang kurang (Silaban, 2014).

Asumsi peneliti ditemukan bahwa kecelakaan sering terjadi di bagian tiang besi pada PT. Kunango Jantan dikarenakan banyaknya sampah besi bekas las yang berserakan, bahan atau alat kerja tidak tersusun rapi sehingga dapat menyebabkan kaki terinjak bahan yang menyebabkan luka dan tubuh, tangan dan kaki tergores. Berdasarkan hasil penelitian masa kerja juga mendukung untuk kondisi tidak aman, pada penelitian ini ditemukan perkerja baru bekerja $<5$ tahun sebanyak 64,9\%. Pekerja yang baru belum memiliki pengalaman dalam bekerja sehingga sehingga sering terjadi teknik yang salah dalam melakukan pekerjaan yang dapat menyebabkan kecelakaan kerja. Diharapkan pimpinan perusahaan dapat meninjau kembali keadaan kerja pada bagian tiang besi dan menyarankan pada pekerja untuk merapikan alat dan bahan serta perusahaan dapat menyediakan tempat pembuangan sampah bekas kerja.

\section{SIMPULAN}

Berdasarkan penelitian yang telah dilakukan di unit tiang besi PT. X Kota Padang dapat disimpulkan sebagai berikut :

1. Kurang dari separuh $(35,1 \%)$ responden pernah mengalami kecelakaan kerja di unit tiang besi PT. X Kota Padang tahun 2017.

2. Kurang dari separuh $(43,2 \%)$ responden memiliki tindakan tidak aman di unit tiang besi PT. X Kota Padang tahun 2017.

3. Kurang dari separuh $(37,8 \%)$ responden memiliki kondisi tidak aman di unit tiang besi PT. X Kota Padang tahun 2017.

4. Ada hubungan yang bermakna antara tindakan dengan kecelakaan kerja di unit tiang besi PT. X Kota Padang tahun 2017.

5. Ada hubungan yang bermakna antara kondisi kerja dengan kecelakaan kerja di unit tiang besi PT. X Kota Padang tahun 2017.

\section{UCAPAN TERIMA KASIH}

Penelitian ini tidak luput dari segala bantuan dan arahan dari berbagai pihak, terutama peneliti mengucapkan terima kasih kepada:

1. Ketua Sekolah Ilmu Kesehatan Alifah Padang dan bagian UPPM yang telah memberi kesempatan untuk peneliti dalam melakukan penelitian.

2. Direktur dan seluruh pekerja di PT X Kota Padang

DAFTAR PUSTAKA

Aditama, 2012. Evaluasi perilaku tindakan tidak aman (unsafe action) dan kondisi tidak aman (unsafe condition) pada proyek kontruksi gedung ruko 
bertingkat di Palangka Raya. Jurnal Skripsi

Arikunto, 2013. Prosedur Penelitian, Jakarta ; PT. Rineka Cipta.

Ferdian, 2016. Hubungan Tindakan FaktorFaktor Yang Berhubungan Tidak Aman (Unsafe Action) dan Kondisi Tidak Aman (Unsafe Condition) Dengan Terjadinya Kecelakaan Kerja pada pekerja di Area Proyek Pembangunan Pabrik Indarung VI tahun 2016. Jurnal Skripsi

Hastono, 2006. Basic Data Analysis For Health Research Training, Jakarta : FKUI

BPJS Ketenagakerjaan, 2016. Kecelakaan Kerja di Riau \& Sumbar Capai 3.576 Kasus, http://www.bisnis.com, diakses tanggal 16 Desember 2016.

Notoatmodjo, S. 2012. Metodologi Penelitian Kesehatan, Rineka Cipta : Jakarta
Ramli, 2010. Sistem Manajemen Keselamatan \& Kesehatan Kerja OHSAS 18001. Jakarta : Dian Rakyat.

Rezeki, 2015. Sanitasi Hygiene dan K3 (Kesehatan dan Keselamatan Kerja), Bandung : Rekayasa Sains.

Saragih, 2014. Faktor-faktor yang Berhubungan dengan Tindakan Tidak Aman pada Pekerja Lapangan PT. Telkom Cabang Sidikalang Kabupaten Dairi tahun 2014. Jurnal Skripsi

Setiadi, 2013. Konsep dan Penulisan Riset Perawatan, Yogyakarta : Graha Ilmu

Silaban, 2014. Keselamatan dan Kesehatan Kerja. Medan.

Sucipto, 2014. Keselamatan dan Kesehatan Kerja, PT. Pustaka Binaman Persindo, Jakarta.

Suma'mur, 2014. Higiene Perusahaan dan Kesehatan Kerja (Hiperkes). Gunung Agung, Jakarta. 